International Journal of Economics, Business and Accounting Research (IJEBAR)

Peer Reviewed - International Journal

Vol-1, Issue-2, 2017 (IJEBAR)

ISSN: 2614-1280, http://www.jurnal.stie-aas/ijebar

\title{
Disclosure of Corporate Social Responsibility (CSR) Through Company \\ Characteristics at Company Listed on LQ45 Indonesia Stock Exchange (IDX)
}

\author{
Budiyono Budiyono ${ }^{1}$, Dewi Maryam ${ }^{2)}$ \\ budiyono_bk@yahoo.co.id, \\ College of Economics Indonesia Surabaya \\ College of Economics Indonesia Surabaya
}

\begin{abstract}
In the era of globalization, environmental awareness has brought about changes in attitudes towards profit orientation of the social orientation of the company. Management as the agent cannot avoid the reality of the impact of corporate activity that not only generates profits / raise stock prices, but also has environmental impacts such as damage to ecosystems, pollution, and so forth. The purpose of this study was to analyze the influence of firm characteristics on corporate social responsibility disclosure in corporate annual reports in Indonesia. The populations in this study are 10 companies listed in the LQ45 index of the Indonesia Stock Exchange (IDX) with the research period of 2011 until 2015 and meet the criteria established. Analysis of the Data used is multiple linear regressions. The results of this study indicate that public ownership, liquidity, and firm size have no significant effect on corporate social responsibility disclosure. Meanwhile, leverage and profitability have a significant effect on corporate social responsibility disclosure.
\end{abstract}

Keywords: corporate social responsibility disclosure, public ownership, leverage, liquidity, profitability, and firm size.

\section{PRELIMINARY}

\begin{tabular}{|c|c|}
\hline $\begin{array}{l}\text { The problem of natural } \\
\text { resource exploitation and } \\
\text { environmental damage due to the } \\
\text { operation of companies that compete } \\
\text { for profit as much as possible } \\
\text { regardless of the social and } \\
\text { environmental impacts that may } \\
\text { occur into the background of the } \\
\text { emergence of the concept of } \\
\text { Corporate Social Responsibility } \\
\text { (CSR). CSR is defined as the } \\
\text { provision of financial and non- }\end{array}$ & $\begin{array}{l}\text { social and physical environment, as } \\
\text { stated in the company's annual report } \\
\text { or a separate social report (Guthrie } \\
\text { and Mathews, 1985). CSR includes } \\
\text { details about the physical } \\
\text { environment, energy, human } \\
\text { resources, products and community } \\
\text { involvement issues. } \\
\text { In Indonesia, the practice of } \\
\text { CSR is getting stronger especially } \\
\text { after the enactment of Law } 40 \text { of } \\
\text { 2007 on Limited Liability Company } \\
\text { (LLC) Article } 1 \text { point } 3 \text { which states } \\
\text { that LLC which carries on business }\end{array}$ \\
\hline
\end{tabular}


ISSN: 2614-1280, http://www.jurnal.stie-aas/ijebar

in the field and/or concerned with natural resources required running CSR. The implementation of the role of social responsibility isset out in Article 74 of Law No. 40 of 2007, and its implementation should be reported in the company's annual report (Article 66 paragraph 2c). CSR is also regulated in Law Number 25 the Year 2007 regarding Investment-related companies listed on the capital market. The regulation describes the obligation for each investor to implement CSR, respecting the cultural traditions of the community around the investment business activity, and comply with all the provisions of the legislation. However, government regulations do not provide specific guidance on how and what information should be reported on CSR activities, so that the disclosure of information about CSR in Indonesia is still considered lacking.

Disclosure of information CSR has undertaken by the company will vary depending on the characteristics of each company. Wallace et. al. (1994) in Cahyono (2010) stated that the characteristics of the company in the context of financial reporting can be classified according to the structure and performance of the company. In this study, the structure of the company can be seen from public ownership, leverage, liquidity, profitability, and firm size. While the category of performance seen from liquidity and profitability.

The research in Indonesia on the effects of corporate characteristics on disclosure CSR by Sembiring (2005). In his research, Sembiring using variables company size, board size, company profiles, leverage, and profitability to represent the characteristics of the company. By using multiple regression analysis, Sembiring obtain the result that the size of the company, board size and company profile and significant influence with positive direction towards CSR. While profitability variable and leverage proved no significant effect on CSR disclosure.

Companies which are listed in LQ45 Index IDX is the 45 companies with the best financial performance. But what about the disclosure of CSR in these companies are? Therefore, this study attempts to examine the effect of company characteristics on disclosure of CSR in companies listed in LQ45 index IDX.

The problem of this research is whether public ownership, leverage, liquidity, profitability, and the size of the company a significant effect on the disclosure of corporate social responsibility (CSR)? With the purpose of the study was to determine whether public ownership, leverage, liquidity, profitability, and company size significantly influence disclosure of corporate social responsibility (CSR).

\section{UNDERLYING THEORY}

\section{Disclosure of Corporate Social Responsibility}

The disclosure of corporate social responsibility which is often also referred to as social disclosure, corporate social reporting, social accounting (Mathews, 1995) or corporate social responsibility (CSR). CSR is a process of communicating the social and 
International Journal of Economics, Business and Accounting Research (IJEBAR)

Peer Reviewed - International Journal

Vol-1, Issue-2, 2017 (IJEBAR)

ISSN: 2614-1280, http://www.jurnal.stie-aas/ijebar

environmental impact of economic activities on the organization of special interest groups and on society as a whole (Hackston and Milne, 1996).

\section{Interest Disclosure Corporate Social Responsibility}

According to Gray, Owen, and Maunders (1988) in Sulistyowati (2004), the purpose of disclosure of corporate social responsibility (CSR) is:

a. To improve the image of the company.

b. To improve the accountability of an organization, with the assumption that there is a social contract between the organization and the community.

c. To provide information to investors.

\section{Disclosure Index Corporate Social Responsibility}

Indicators used to measure the disclosure of corporate social responsibility (CSR) in this research is using the items contained in the journal Eddy Rismanda Sembiring 2005, which uses seven categories: environment, energy, health and safety of workers, other labor, product, community involvement and the public. This category is adopted from Hackston research and Milne (1996).

\section{Company Characteristics}

Company characteristics is company-specific characteristics that distinguish it from other companies. In this study, the characteristic of the company which is expected to affect the disclosure of corporate social responsibility is public ownership, leverage, liquidity, profitability, and firm size.

\section{Public Shareholding}

Public ownership is the proportion of ownership interest held by the public/community towards the company's shares. This value is used to give an idea of the influence of public ownership on the disclosure of corporate social responsibility (CSR). The greater the shares owned by the public, the more the information disclosed in the annual report, investors want to obtain information as possible about where to invest and be able to supervise the activities of the management, so that the interests of the company are met (A'inun Na'im and Fuad Rakhman, 2000). Puspitasari (2009) and Amalia (2005) shows that public ownership has a positive influence on CSR. Inconsistent results are shown by Cahyono (2010), Rahajeng (2010),

H1: Public net share ownership has significant effect on disclosure corporate social responsibility (CSR).

\section{Leverage}

Leverage is the ratio between the debt with assets. Debt to Equity Ratio (DER) is part of the leverage ratio which shows the proportion of debt and equity used by the company in its operations. The ratio is used to provide an overview of the capital structure of the company, so it can be seen the level of risk of noncollection of a debt. Companies that have a high DER value reflects the company's financial risk even greater because the debt will cause permanent attachment to the company in the form of an obligation to pay interest charges along with 


\section{Vol-1, Issue-2, 2017 (IJEBAR)}

ISSN: 2614-1280, http://www.jurnal.stie-aas/ijebar

periodic principal repayments obligations, compared with the company DER lower ratio. Sulkowski et. al (2010), Cormier and Magnan (2003), Meek et. al. (1995), Yuen et. al., and Cahyono (2010) states that leverage negatively affects CSR disclosure. However, Miranti (2009), Razeed (2010), and ElijidoTen (2004) showed no effect on the leverage of CSR disclosure.

$\mathrm{H} 2$ : Leverage has no significant effect on disclosure bear Corporate social responsibility (CSR).

\section{Liquidity}

The company's liquidity is a condition that indicates the company's ability to fund its operations and repay short-term debt. This ratio is used to provide a picture of the effect of the availability of funds companies on the disclosure of corporate social responsibility (CSR). Companies that are financially healthy, is likely to be more revealing than the company's CSR information that liquidity is low. It is based on the financial strength of a company which will tend to provide more extensive information than companies that have a weak financial condition (Cooke, TE, 1991). Andi Kartika (2010), Rahajeng (2010), and Sutomo (2004) which stated that the liquidity negatively affects CSR disclosure.

H3: liquidity has significantly effect to the disclosure responsibilities answer social (CSR).

\section{Profitability}

Profitability is the ability of the company makes a profit in relation to sales, total assets, or equity (Sartono, 1998). This ratio is used to provide a picture of how effectively the company is operating so as to produce profits for the company. Companies with low profitability levels will be more focused on improving their economic performance and give less attention to the environment (Elijido-Ten, 2004). In line with that statement, Meek et. al. (1995) states that companies with a high level of profitability that have more resources to carry out the environmental disclosure. Razeed (2010), Miranti (2009), and Cahyono (2010) showed that the positive effect on the profitability of environmental disclosure.
H4: Profitability influential significantly to disclosures corporate social responsibility (CSR).

\section{Company Size}

According to Ferry and Jones in Jaelani (2001: 79) the size of the company described the size of a company in which the size of the size of the company can be seen on the size of capital employed, total assets owned, or total sales earned. This value is used to give an overview of the company's ability to express corporate social responsibility (CSR). Large companies are listed companies that mostly highlighted by the stakeholders, this is because large companies have a great impact on the environment, both in the use of sources of raw materials, energy sources, as well as hazardous waste treatment as well as large companies have more adequate resources so as to allow to provide relevant 
information to stakeholders in a larger number and broader than the small firms (Kokubu et. al., 2002). Sembiring (2005), Farook and Lanis (2005), Reverte (2008), Nurkhin (2009), Murcia \& Souza (2009), Yuen et. al. (2009), and Waryanto (2010). Miranti has shown inconsistent results (2009), ElijidoTen (2004), and Permatasari (2009) which indicates that company size (size) does not affect the disclosure of CSR.

H5: Firm size has significant effect to disclosures bear social responsibility (CSR).

\section{Legitimacy Theory}

Legitimacy can be considered as the perception or assumption that the actions taken by an entity are the desired action, appropriate or in accordance with the system of norms, values, beliefs, and definitions developed social (Suchman, 1995 in Rosita Chandra, 2009). Legitimacy is considered important for the company due to the company's public legitimacy becomes a strategic factor for the development of the future company. The rationale for this theory is the organization will continue its existence if the public realized that the organization operates to the value system commensurate with the value system of society itself.

\section{Stakeholder Theory}

Stakeholder theory assumes that the existence of a company is determined by stakeholders. Companies are trying to find a justification of the stakeholders in running the company's operations. The stronger the position of stakeholders, the greater the tendency of companies to adapt themselves to the wishes of the stakeholders. Trekers (1983) stated that the stakeholder theory is a system that is explicitly based on the idea of an organization and its environment, recognizing the nature of the interplay between the two is complex and dynamic. Robert (1992) stated that corporate social disclosure is a successful tool for companies to negotiate relationships with stakeholders.

\section{RESEARCH METHODS Population and Sample}

The population in this study is a company registered in LQ45 Indonesia Stock Exchange (IDX), which published its annual report her during the period 2011-2015. The criteria used to determine the population is as follows:

1. Companies listed on the Stock Exchange LQ45 Index.

2. Companies listed consecutively on LQ45 index IDX period 2011-2015.

3. Companies listed on the LQ45 index IDX published annual reports in a row during the period 2011-2015.

4. Companies listed on the LQ45 index IDX who has information about the variables required in this study.

5. Companies listed on the LQ45 index IDX published financial statements in the currency Rupiah (Rp).

\section{Types and Sources of Data}

The data used in this research is quantitative data that is data in the form of figures obtained from the official website. In this study, 
quantitative data obtained from www.idx.co.id. The data sources used in this research are secondary data obtained from annual report companies listed in LQ45 Indonesia Stock Exchange (IDX) during the period 2011 - 2015. Secondary data sources in this study can be obtained from reports of knowledge available on the IDX corner Brawijaya University, and other sources.

\section{Method of collecting data}

In this study, the data were collected by using the method of documentation about things and documents related to the study variables. The required data include information about the disclosure of information relating to corporate social responsibility (CSR) can be taken from the annual report and / or sustainability reports companies, while the data for the measurement of public ownership, leverage, liquidity, profitability, and the size of the company is taken from the financial statements of companies listed in the report of the company.

$$
\text { CSRDI }=\frac{X}{n}
$$

$$
\begin{array}{ll}
\text { CSRDI : } & \text { Corporate Social } \\
& \text { Index Company. } \\
\mathbf{X} & : \text { Number of items } \\
& \text { social responsibility } \\
& \text { that disclosed } \\
& \text { : The total number of items } \\
& \text { CSR expected company }
\end{array}
$$

\section{Public Ownership}

Public ownership shows how big the company shares held by the public. Public ownership can be seen in the financial statements. Public ownership is measured by dividing

\section{Operational Definition}

\section{Disclosure of Corporate Social Responsibility}

Checklist did by looking at the disclosure of corporate social responsibility (CSR) in seven categories: environment, energy, health and safety of workers, other workers, products, community involvement, and the public. This category is adopted from research conducted by Hackston and Milne (1996). The seventh category is divided into 90 items of disclosure. Based on Capital Market and Financial Institution Supervisory Agency Regulation No. VIII.G.2 of the annual report and the suitability of the item is to be applied in Indonesia, the adjustment then done. 12 items eliminated because it is less suitable to be applied to the conditions in Indonesia so in total the remaining 78 items of disclosure. 78 items is then adjusted back to their respective industry sectors so that the items of disclosure expected from each different sector. Furthermore,

$$
\begin{aligned}
& \text { Responsibility Disclosure } \\
& \text { disclosure of information } \\
& \text { company (CSR) } \\
& \text { company. } \\
& \text { disclosure of information } \\
& \text { to be revealed }
\end{aligned}
$$

the number of shares held by the public with overall total shares.

\section{Leverage}

Debt to Equity (DER), the use of debt compared to the size of 
International Journal of Economics, Business and Accounting Research (IJEBAR)

Peer Reviewed - International Journal

Vol-1, Issue-2, 2017 (IJEBAR)

ISSN: 2614-1280, http://www.jurnal.stie-aas/ijebar

equity capital of the company. This ratio shows the proportion of debt and equity used by the company in its operations. DER is calculated by dividing total debt by total equity.

\section{Liquidity}

Companies that have high liquidity is expected to perform disclosure more broadly. Liquidity is measured by dividing current assets by current liabilities of the company. Symbolized by the current ratio (CR). This ratio describes the ability to pay the debt immediately be met with current assets.

\section{Profitability}

Return on Equity (ROE) demonstrate the company's ability to generate profit after tax by using their own capital. ROE is a measure of profitability from the perspective of shareholders, which can be compared between companies and to indicate the level of profitability of an industry with more so widely used in research to measure the profitability of a company.

\section{Company Size}

The size of the company is a small number of companies viewed from various aspects, in this research the company size is measured by total assets of the company transformed into the natural logarithm. Total assets are transformed in logarithms aim to equalize with another variable because the total assets of the company are relatively large compared with other variables in this study.

\section{RESULTS AND DISCUSSION}

The results of multiple regression analysis with the dependent variable disclosure of corporate social responsibility and the independent variables consist of public ownership, leverage, Liquidity, profitability, and the size of the company, as well as the regression coefficients as listed in Table 1 below:

$$
Y=-27.926-0.068 X_{1}-0.044 X_{2}+0.008 X_{3}-0.192 X_{4}+2.504 X_{5}+e
$$

Table 1

The Results of Multiple Linear Regression Test

\begin{tabular}{|l|c|c|c|}
\hline \multirow{2}{*}{ Model } & Unstandardized & \multirow{2}{*}{ Significant } & \multirow{2}{*}{ Result } \\
\cline { 2 - 3 } & B & & \\
\hline (Constant) & -27926 & 0473 & - \\
\hline Public shareholding (\%) & -0068 & 0382 & Not significant \\
\hline Leverage (\%) & -0044 & 0010 & Significant \\
\hline Liquidity (\%) & 0008 & 0154 & Not significant \\
\hline Profitability (\%) & -0192 & 0019 & Significant \\
\hline Size & 2,504 & 0054 & Not significant \\
\hline
\end{tabular}

Source: Results of data processed in 2016 


\section{First Hypothesis Testing}

The result of the calculation of the variable public ownership on the disclosure of corporate social responsibility (CSR) values obtained p-value amounted to 0.382 , where the $\mathrm{p}$-value is greater than the significance value that is equal to 0.05 . This proves that public ownership variables did not significantly affect CSR disclosure.

The results of this study cannot support the theory stakeholder who wants the company to disclose information to the public shareholders CSR more broadly. Based on the test results of descriptive statistics in this study, discovered that the average public shareholding companies listed in LQ45 Indonesia Stock Exchange (BEI) only amounted to $31.33 \%$, while the controlling shareholders have at least a 50\% stake. The low composition causes the public shareholders to have a weak influence on managerial decisions, including in terms of CSR information disclosure decisions. The reason that might explain why the proportion of public ownership has no effect on the disclosure of CSR information is public shareholders generally a small investor,

The results of this research are inconsistent with Amalia (2005) which states that the proportion of public shares owner broad influence on CSR. The more shares held by the public, so the more parties who need information about the company, so the more grains of detailed information required to be opened in the annual report. The results of this study are consistent with Cahyono
(2010), Rahajeng (2010) and Son (2011) which showed that public ownership does not affect the disclosure of CSR.

\section{Second Hypothesis Testing}

Variable calculation results leverage on the disclosure of corporate social responsibility (CSR) values obtained p-value of 0.010 , where the p-value is smaller than the significance value that is equal to 0.05 . This proves that the variable leverage significant effect on CSR disclosure.

This study supports the idea Belkaoui successful and Karpik (1989) which states that the company level Leverage high will express fewer CSR information. The higher the level of leverage of the company, the more likely the company will violate the credit agreement so that the company will try to report higher profits now. So that reported higher earnings, then the manager should reduce costs, including costs to disclose information CSR (Belkaoui and Karpik, 1989). This is consistent with Sulkowski et. al. (2010) which states that companies with high leverage tend to have more legal and environmental issues, so it will reduce CSR disclosure in its annual report.

The results of this study are consistent with previous research conducted by Sulkowski et. al.(2010), Comier and Magnan (2003), Yuen (2009), and Cahyomo (2010) which stated that the leverage negatively affects CSR disclosure. However, these results contradict the results of research conducted by Miranti (2009), Razeed (2010), and Elijido-Ten (2004), which indicates 


\section{Vol-1, Issue-2, 2017 (IJEBAR)}

ISSN: 2614-1280, http://www.jurnal.stie-aas/ijebar

that the leverage does not affect the disclosure of CSR.

\section{Third Hypothesis Testing}

The results of the liquidity variable calculation on the disclosure of corporate social responsibility (CSR) values obtained p-value amounted to 0,154 , of which p-value is greater than the significance value that is equal to 0.05 . This proves that liquidity variables did not significantly affect CSR disclosure.

The results of this study showed that the greater the level of liquidity of the company does not necessarily affect the disclosure of CSR information more widely. The results also have not been able to support the legitimacy theory which states that the company's strength shown by the high liquidity ratio to be associated with a high level of CSR disclosure anyway (O'Donovan, 2000).

The results of this study are consistent with results of previous studies conducted by Andi Kartika (2010), Rahajeng (2010), and Sutomo (2004) stated that liquidity does not affect the disclosure CSR. And the results of this study is unable to support research and Suhendra Syarir (2010) which showed that the positive effect on the liquidity of CSR disclosure.

\section{Fourth Hypothesis Testing}

The result of the calculation of the profitability variable on the disclosure of corporate social responsibility (CSR) values obtained p-value amounted to 0,019, of which p-value is smaller than the significance value that is equal to 0.05 . This proves that the variables significantly influence the profitability of CSR disclosure.

The results of this study indicate that companies listed in LQ45 Indonesia Stock Exchange (BEI), which have high profitability is not necessarily more disclosure of CSR information. This is because the company's management will still reveal the necessary reports although the company's profitability down or up because companies need to disclose the information required by investors. This is consistent with the stakeholder theory because the group that is the main consideration for the company to disclose or not to discloses information in the financial statements (Fatayaningrum, 2011).

This research resulted in different findings of the research conducted by Sembiring (2003 and 2005), Anggraini (2006), Branco and Rodriguez (2008), and Reverte (2008). The four were found the same results that profitability is not proven to have any impact on CSR. However, this study is consistent with the results Razeed (2010), Miranti (2009), Rahajeng (2010), and Cahyono (2010) which showed that the effect on the profitability of CSR disclosure.

\section{Fifth Hypothesis Testing}

The results of the calculation of variable size companies on the disclosure of corporate social responsibility (CSR) values obtained $\mathrm{p}$-value amounted to 0,054 , of which p-value is greater than the significance value that is equal to 0.05 . This proves that the variable size of the companies did not significantly affect CSR disclosure.

The results of this study cannot support the idea Kokubu et. al. 
(2002) which stated that the greater the size of the company, CSR disclosures made by the company will be more numerous and widespread. The results of this study found that the size of the company does not have a significant impact on the disclosure of CSR, which means the greater the size of the company is not necessarily the level of CSR disclosure by the company will always be more extensive. This condition indicates that in order to gain legitimacy, large companies will not always do CSR more in order to have an influence on those internal or external parties who have an interest in the company. This is because the CSR is no longer a mere activity, but it is an obligation for companies that are used to maintain the viability of the company,

The results of this study are consistent with previous research conducted by Miranti (2009), Elijido-Ten (2004), and Permatasari (2009) which states that the size of the company negatively affect CSR disclosure. And these results contradict research Belkaoui and Karpik (1989), Adam et. al., (1995, 1998), Hackston and Milne (1996), Kokubu et. al., (2001), Hasibuan (2001), Sembiring (2005) and Anggraeni (2006) proved the effect of firm size on disclosure of CSR.

\section{Research Implications Theoretical implications}

The results showed that there are characteristics that are owned by the company that could affect or not affects the disclosure of corporate social responsibility (CSR) in the company's annual report.

\section{Practical implications}

The results of this study also found that disclosure of corporate social responsibility (CSR) by the company listed in LQ45 Indonesia Stock Exchange (IDX) is still low. This is because the company still considers CSR as an expense that would reduce profits to be received firm rather than as a long-term investment for the company that will benefit the company in the form of ensuring the survival of the company.

\section{CONCLUSIONS AND RECOMMENDATIONS}

\section{Conclusion}

Based on the research that has been done, then it can be concluded that:

1. Public ownership significant negative effect on the disclosure of corporate social responsibility (CSR), this indicates that public shareholders have a weak influence on managerial decisions of the company, including in CSR disclosure decisions.

2. Leverage significant negative effect on disclosures CSR Results this research show that companies with Leverage High will reveal a little more information about CSR.

3. Liquidity has no significant positive effect on the disclosure of CSR. The greater the level of liquidity of the company does not necessarily affect the information in broader CSR information.

4. Profitability influential negative significant against disclosures CSR. Result this research show that company that has level high 
ISSN: 2614-1280, http://www.jurnal.stie-aas/ijebar

profitability not yet certainly more revealing information CSR.

5. Size of the company has no significant positive effect of disclosure CSR. Results of the research have shown that the larger the size of the company not necessarily the level of CSR disclosure by the company will always be more extensive.

\section{Suggestion}

From the conclusions of this research, the suggestions can be made are:

1. For the expected management can more fully in revealing information about the company's activities related to financial performance and corporate governance in the company's annual report and disclose activities corporate social responsibility (CSR) for your information additional. Related with corporate performance reporting to the stakeholders.

2. For the government expected be able to formulate a law clearer disclosure CSR considering regulations. The current law still does not give clear guidelines on how and what information should be reported companies regarding disclosure of CSR, so CSR reported by the company is still deemed less.

\section{BIBLIOGRAPHY}

Ainun Na'im dan Fuad Rakhman, 2000, Analisis Hubungan Antara Kelengkapan Pengungkapan Laporan
Keuangan dengan Struktur Modal dan Tipe Kepemilikan Perusahaan, Jurnal Riset Akuntansi Indonesia, Volume 15, BPFE UGM, Yogyakarta. Anggraini, Fr. Reni Retno, 2006. Pengungkapan Informasi Sosial dan Faktor-Faktor yang Mempengaruhi Pengungkapan Informasi Sosial dalam Laporan Keuangan Tahunan: Studi Empiris pada Perusahaan-Perusahaan yang Terdaftar di Bursa Efek Jakarta. Simposium Nasional Akuntansi 9, Padang.: 1-21.

Anifa Irawati, 2011, Pengaruh Karakteristik Perusahaan terhadap Luas Pengungkapan Tanggung Jawab Sosial (Social Disclosure) pada Perusahaan Real Estate and Property di Bursa Efek Indonesia, Skripsi Fakultas Ekonomi dan Bisnis Universitas Brawijaya, Malang.

Anonim, 2007, Undang-Undang Nomor 25 Tahun 2007 tentang Penanaman Modal, Jakarta.

Anonim, 2007, Undang-undang Nomor 40 Tahun 2007 tentang Perseroan Terbatas, Jakarta.

Belkaoui, A. and Karpik, P.G, 1989, Determinants of The Corporate Decision to Disclose Social Information, Accounting, Auditing \& Accountability Journal, Vol. 2, No. 1, pp. 36-51.

Belkaoui. A., 1976. The Impact of The Disclosure of The Environmental Effects of Organizations Behaviour on The Market, Financial Management, Vol. 5, pp. 2631. 
Bowen, N. dan Deegan, C., 1998, The Public Disclosure of Environmental Performance Information: A Dual Test of Media Agenda Setting Theory and Legitimacy Theory, Accounting and Business Research, Vol. 29:1, pp. 2141.

Eka Nanda Putra, 2011, Pengaruh Karakteristik Perusahaan Terhadap Pengungkapan Corporate Social Responsibility (CSR), Journal of Business Finance and Accounting, Fakultas Ekonomi Universitas Dipenogoro, Semarang.

Elijido-Ten, E., 2004, Determinants of Environmental Disclosures in A Developing Country: An Application of The Stakeholder Theory. Accepted for Presentation at the fourth Asia Pacific Interdisciplinary Research in Accounting Conference 4 to 6 July 2004, Singapore.

Elkington, J., 1997, Cannibals with Forks: The Triple Botton Line of 21 st century Business, Oxford, Gray, R., Owen, D., and Maunders, K., 1988, Corporate Social Reporting: Emerging Trends in Accountability and The Social Contract, Accounting, Auditing and Accountability Journal, Vol. 1, No. 1, pp. 6-20.

Hackston, David, and Milne, Marcus J., 1996, Some Determinants of Social and Environmental Disclosures in New Zaeland Companies, Accounting, Auditing and Accountability
Journal, Vol. 9, No. 1, pp. 77108.

Haniffa, R. M. and T. E. Cooke., 2005, The Impact of Culture and Governance on Corporate Social Reporting. Journal of Accounting and Public Policy 24, pp. 391- 430.

Imam Ghozali, 2001, Aplikasi Analisis Multivariate dengan Program SPSS, Badan Penerbit Universitas Diponegoro, Semarang.

Kurnia Eka Wulandari, 2012, Pengaruh Karakteristik Perusahaan Terhadap Pengungkapan Informasi Lingkungan, Skripsi Fakultas Ekonomi dan Bisnis Universitas Brawijaya, Malang.

Marfu'ah dan Cahyo, Y. D., 2011, Karakteristik Perusahaan dan Pengungkapan Tanggung Jawab Sosial, Jurnal Akuntansi dan Auditing Indonesia, Vol.15, No.1, Hal 103-119.

Meek, R. dan Gray., 1955, Analisis Pengaruh Faktor-Faktor Fundamental Perusahaan Terhadap Kelengkapan Laporan Keuangan.

Rahajeng, R. G., 2010, FaktorFaktor yang Mempengaruhi Pengungkapan Sosial Perusahaan, Skripsi Universitas Dipenogoro, Semarang.

Sembiring, E. R., 2003, Kinerja Keuangan, Political Visibility, Ketergantungan Pada Hutang, dan Pengungkapan Tanggung Jawab Perusahaan, imposium Nasional Akuntansi VI 
International Journal of Economics, Business and Accounting Research (IJEBAR)

Peer Reviewed - International Journal

Vol-1, Issue-2, 2017 (IJEBAR)

ISSN: 2614-1280, http://www.jurnal.stie-aas/ijebar

Sembiring, E. R., 2005, Karakteristik

Perusahaan dan Pengungkapan

Tercatat di Bursa Efek Jakarta,

Tanggung Jawab Sosial: Studi

Prociding paper, Simposium

Empiris pada Perusahaan yang

Nasional Akuntansi 8, Solo-

Indonesia 